\title{
Hexavalent chromium intoxication induces intrinsic and extrinsic apoptosis in human renal cells
}

\author{
YEN-HUNG WU ${ }^{1,2}$, JHONG-CHING LIN $^{1}$, TZU-YI WANG ${ }^{1}$, TZENG-JIH LIN ${ }^{3}$, MENG-CHI YEN ${ }^{1,2}$, \\ YAO-HUA LIU ${ }^{1}$, PEI-LIN WU ${ }^{1}$, FEN-WEI CHEN ${ }^{1}$, YUEH-LUN SHIH ${ }^{1}$ and I-JENG YEH ${ }^{1,2}$ \\ ${ }^{1}$ Department of Emergency Medicine, Kaohsiung Medical University Hospital, Kaohsiung Medical University;
${ }^{2}$ Graduate Institute of Clinical Medicine, College of Medicine, Kaohsiung Medical University, Kaohsiung 807;
${ }^{3}$ Department of Family Medicine, Taoyuan Branch, Taipei Veterans General Hospital, Taoyuan 330, Taiwan, R.O.C.
}

Received March 26, 2019; Accepted November 22, 2019

DOI: $10.3892 / \mathrm{mmr} .2019 .10885$

\begin{abstract}
Hexavalent chromium [Cr(VI)], is a well-known toxic form of the heavy metal chromium in the natural environment. Clinical evidence has indicated that exposure to $\mathrm{Cr}(\mathrm{VI})$ can cause severe renal damage. The production of reactive oxygen species (ROS) due to intracellular reduction of $\mathrm{Cr}$ (VI) is the main mechanism underlying the induction of cellular dysfunction and apoptosis. The present study aimed to investigate in detail the apoptotic pathways induced by $\mathrm{Cr}(\mathrm{VI})$-exposure in a human immortalized proximal tubular epithelial cell line HK-2, in order to understand the mechanism involved therein. Exposure to $10 \mu \mathrm{M}$ potassium dichromate $\left(\mathrm{K}_{2} \mathrm{Cr}_{2} \mathrm{O}_{7}\right)$, a toxic compound of $\mathrm{Cr}(\mathrm{VI})$, significantly decreased cell viability after 24 and $48 \mathrm{~h}$ of incubation and induced intracellular ROS generation. The expression levels of markers that activate the apoptotic pathway including cleaved caspase-3 and poly (ADP-ribose) polymerase were significantly upregulated in $\mathrm{K}_{2} \mathrm{Cr}_{2} \mathrm{O}_{7}$-exposed $\mathrm{HK}-2$ cells. In addition, the induction of intrinsic and extrinsic apoptotic markers was detected in $\mathrm{K}_{2} \mathrm{Cr}_{2} \mathrm{O}_{7}$-exposed HK-2 cells. In summary, the present study described for the first time the novel apoptotic mechanism of $\mathrm{Cr}(\mathrm{VI})$-toxicity in human renal cells which may be beneficial in designing optimal clinical treatment for renal damage caused by acute $\mathrm{Cr}(\mathrm{VI})$ toxicity.
\end{abstract}

Correspondence to: Dr I-Jeng Yeh, Department of Emergency Medicine, Kaohsiung Medical University Hospital, Kaohsiung Medical University, 100 TzYou 1st Road, Kaohsiung 807, Taiwan, R.O.C.

E-mail: ijengyeh@hotmail.com

Abbreviations: $\mathrm{Cr}(\mathrm{VI})$, hexavalent chromium; ROS, reactive oxygen species; $\mathrm{Cr}(\mathrm{III})$, trivalent chromium; PARP, poly (ADP-ribose) polymerase; AIF, apoptosis-inducing factor

Key words: cell death, extrinsic apoptosis, intrinsic apoptosis, hexavalent chromium, human proximal tubular epithelial cell

\section{Introduction}

Chromium is the sixth most abundant element in the earth's crust. Trivalent $\mathrm{Cr}$ (III) and hexavalent $\mathrm{Cr}$ (VI) chromium are the most stable oxidative states occurring in nature. $\mathrm{Cr}$ (VI) is more cytotoxic than $\mathrm{Cr}$ (III) due to its stronger oxidizing capacity and rapid absorption by the cells through non-specific anion carriers $(1,2)$. Toxic $\mathrm{Cr}(\mathrm{VI})$ can be released into the environment through soil, sea water, and fresh water. As a result, individuals may be at a risk of exposure to $\mathrm{Cr}$ (VI) when consuming contaminated drinking water $(3,4)$. The development of an optimal treatment scheme against acute or chronic $\mathrm{Cr}(\mathrm{VI})$ exposure remains a critical issue.

When $\mathrm{Cr}$ (VI) enters the cells, it can be rapidly reduced into $\mathrm{Cr}(\mathrm{III})$, resulting in the production of several reactive chromium intermediates and reactive oxygen species (ROS), all of which are responsible for altering normal cellular function and promoting apoptosis $(5,6)$. Potassium dichromate $\left(\mathrm{K}_{2} \mathrm{Cr}_{2} \mathrm{O}_{7}\right)$ is a toxic compound of $\mathrm{Cr}(\mathrm{VI})$ that has been demonstrated to induce nephrotoxicity in humans and animals (7). In a clinical setting, acute and chronic $\mathrm{Cr}$ (VI) exposure can cause severe damage to proximal renal tubular cells and result in significant renal function deterioration, thereby requiring hemodialysis (8-11). $\mathrm{Cr}(\mathrm{VI})$ toxicity causes acute tubular necrosis, whereby $\mathrm{Cr}(\mathrm{VI})$ directly damages the tubular epithelium (12). Less frequently, $\mathrm{Cr}(\mathrm{VI})$ also causes interstitial renal injury $(13,14)$. Furthermore, $\mathrm{Cr}$ exposure can lead to hepatorenal syndrome, severe coagulopathy, and intravascular hemolysis that may indirectly contribute to the aggravation of renal dysfunction (13).

$\mathrm{Cr}(\mathrm{VI})$ induces free radical production by Fenton-type or Haber-Weiss reaction or by reacting directly with cellular molecules, triggering multiple possible apoptotic signaling pathways in various cell types $(15,16)$. Several studies have suggested that $\mathrm{Cr}(\mathrm{VI})$ toxicity induced cell apoptosis mainly via intrinsic mitochondrial pathways in several types of cells, including human tumor cell lines, anterior pituitary cells, hepatocytic cells, and also in a rat model $(5,17-19)$. Although ROS is also linked to the extrinsic apoptotic pathway (20), it is not well understood whether the extrinsic apoptotic pathway is induced in renal cells post- $\mathrm{Cr}(\mathrm{VI})$ exposure. The aim of the present study was to investigate the activation of the extrinsic 
apoptotic pathway in $\mathrm{Cr}(\mathrm{VI})$-exposed HK-2 human immortalized proximal tubular epithelial cell line HK-2.

\section{Materials and methods}

HK- 2 cell culture. HK- 2 cells (ATCC CRL-2190), an immortalized proximal tubular epithelial cell line derived from normal adult human kidneys, were purchased from the American Type Culture Collection. Culture conditions have been described in our previous study (21).

3-(4,5-dimethylthiazol-2-yl)-2,5-diphenyl-tetrazolium bromide (MTT) assay for cell viability. To determine the toxicity of chromium on kidney cells, HK-2 cells $\left(1 \times 10^{4}\right.$ cells) were seeded in each well of a 96-well culture plate (Falcon; BD Biosciences) in triplicates. The cells were exposed to potassium dichromate $\left(\mathrm{K}_{2} \mathrm{Cr}_{2} \mathrm{O}_{7}\right.$; Sigma-Aldrich; Merck $\left.\mathrm{KGaA}\right)$, which was used as the source of chromium (VI), at concentrations of $0.1,0.3,1,10$, 30 , and $100 \mu \mathrm{M}$ for 24,48 , and $72 \mathrm{~h}$. Cell viability was directly examined by an Eclipse Ti-U inverted microscope (Nikon Corporation) at a magnification of $\mathrm{x} 400$ and indirectly assayed by an MTT assay (Sigma-Aldrich; Merck KGaA) according to the manufacturer's instructions. The absorbance at $570 \mathrm{~nm}$ was determined using a microplate reader (Multiskan EX; LabSystems).

Oxidative stress assay. HK- 2 cells $\left(1 \times 10^{6}\right)$ were incubated in 10 -cm dishes with $5 \mu \mathrm{M} \mathrm{2} 7^{\prime}$ '-dichlorofluorescein diacetate (Sigma-Aldrich; Merck KGaA) at $37^{\circ} \mathrm{C}$ for $30 \mathrm{~min}$. After centrifugation $(1,000 \mathrm{x} \mathrm{g})$ and washing in phosphate-buffered saline, the HK-2 cells were exposed to $10 \mu \mathrm{M} \mathrm{K}_{2} \mathrm{Cr}_{2} \mathrm{O}_{7}$ each in triplicates. After $30 \mathrm{~min}$ of incubation, the fluorescence intensity, which is correlated to the concentration of hydroxyl radicals, was detected by Partec CyFlow (Sysmex Partec $\mathrm{GmbH}$ ). The data were analyzed by FCS Express 4 Flow Cytometry (De Novo Software). All procedures were performed in the dark on ice.

Western blotting. Protein lysates were extracted using radioimmunoprecipitation lysis buffer (Amresco, LLC) containing $1 \%$ proteinase inhibitor on ice for $20 \mathrm{~min}$. Proteins were quantified using the protein assay kit (based on Bradford method, Bio-Rad Laboratories, Inc.) and $30 \mu \mathrm{g}$ protein per lane was loaded and separated by $10 \%$ sodium dodecyl sulfate-polyacrylamide electrophoresis at $100 \mathrm{~V}$ for $1 \mathrm{~h}$. The separated proteins were transferred onto Hybond-P polyvinylidene difluoride membranes (Amersham Biosciences; GE Healthcare) and blocked with $3 \%$ bovine serum albumin in Tris-buffered saline containing Tween-20 for $1 \mathrm{~h}$. The membranes were incubated overnight at $4^{\circ} \mathrm{C}$ with commercial primary monoclonal antibodies against poly (ADP-ribose) polymerase (PARP; catalogue number 9542S, 1:1,000; Cell Signaling Technology, Inc.), pro-caspase-3 (catalogue number 06-735, 1:1,000; EMD Millipore), cleaved caspase-3 (catalogue number C8487, 1:1,000; Sigma-Aldrich; Merck KGaA), Bcl-2 (catalogue number 658702, 1:1,000; BioLegend, Inc.), Bax (catalogue number 5023, 1:1,000; Cell Signaling Technology, Inc.), cytochrome $c$ (catalogue number 05-479, 1:500; EMD Millipore), Fas ligand (FasL; catalogue number 68405, 1:500), apoptosis-inducing factor (AIF; catalogue number 4642,
1:1,000), pro-caspase-8 (catalogue number 9746S, 1:1,000) and cleaved caspase-8 (catalogue number 9496S, 1:1,000; all from Cell Signaling Technology, Inc.). Then, the membranes were incubated with goat anti-mouse IgG horseradish peroxidase (HRP)-conjugated antibodies (catalogue number 405306, 1:5,000) or anti-rabbit IgG HRP-conjugated antibodies (catalogue number 410406, 1:10,000; both from BioLegend, Inc.) at room temperature for $1 \mathrm{~h}$. $\beta$-actin (catalog number MAB1501, 1:1,000; Chemicon; EMD Millipore) was used as an endogenous control and detected by the same secondary antibodies as aforementioned. Target proteins were visualized using Clarity $^{\mathrm{TM}}$ Western ECL Substrate (Bio-Rad Laboratories, Inc.) and HyBlot CL film (Denville Scientific, Inc.). The intensities of the bands were quantified with ImageJ software 1.52a (NIH).

Statistical analysis. All results were expressed as the mean \pm standard deviation (SD) of at least three independent experiments. Data were analyzed by analysis of variance (ANOVA) using SPSS20 software (IBM Corp.). Scheffe's test was used for post hoc analysis to compare all pairs of groups of the ANOVA test. Results were considered statistically significant at a value of $\mathrm{P}<0.05$.

\section{Results}

Cr(VI) exposure decreases cell viability and alters the morphology of HK-2 cells. To evaluate the toxic effect of $\mathrm{Cr}(\mathrm{VI})$ on renal tubular cells, a normal human proximal tubule epithelial cell line HK-2 was treated with different concentrations of $\mathrm{K}_{2} \mathrm{Cr}_{2} \mathrm{O}_{7}$, which produced $\mathrm{Cr}(\mathrm{VI})$ in aqueous solution. Various concentrations of $\mathrm{K}_{2} \mathrm{Cr}_{2} \mathrm{O}_{7}$ were added into culture medium and the cell viability was evaluated at 24 and $48 \mathrm{~h}$ post $-\mathrm{K}_{2} \mathrm{Cr}_{2} \mathrm{O}_{7}$ intoxication. The viability of $10-\mu \mathrm{M}$ $\mathrm{K}_{2} \mathrm{Cr}_{2} \mathrm{O}_{7}$-treated cells was approximately $50-60$ and $20-30 \%$, at 24 and $48 \mathrm{~h}$, respectively (Fig. 1A). To evaluate the toxic effect of $\mathrm{K}_{2} \mathrm{Cr}_{2} \mathrm{O}_{7}$ for 24-72 h, similar viability was obtained and is presented in Fig. 1B, compared to the control cells. The morphology of $10-\mu \mathrm{M} \mathrm{K}_{2} \mathrm{Cr}_{2} \mathrm{O}_{7}$-treated cells was altered. Significant cell shrinkage was observed when compared to the control cells (Fig. 1C). These results indicated that the morphology and viability of HK-2 cells were significantly affected upon exposure to $10 \mu \mathrm{M} \mathrm{K}_{2} \mathrm{Cr}_{2} \mathrm{O}_{7}$ for 24-72 $\mathrm{h}$.

Cr(VI) exposure increases intracellular ROS production in $H K-2$ cells. Previous studies have suggested that the production of ROS during the reduction of $\mathrm{Cr}(\mathrm{VI})$ to $\mathrm{Cr}(\mathrm{III})$ promoted apoptosis $(5,6)$. Thus, the intracellular level of ROS was assessed in HK-2 cells exposed to 10 and $100 \mu \mathrm{M}$ of $\mathrm{K}_{2} \mathrm{Cr}_{2} \mathrm{O}_{7}$ for $30 \mathrm{~min}$ (Fig. 2A). The results revealed that the intracellular ROS level in 10 and $100 \mu \mathrm{M} \mathrm{K}_{2} \mathrm{Cr}_{2} \mathrm{O}_{7}$-exposed HK-2 cells was greater than that in control cells. Quantification of data also revealed similar results (Fig. 2B). A high level of ROS may be a factor that triggers cell death in $\mathrm{K}_{2} \mathrm{Cr}_{2} \mathrm{O}_{7}$-exposed $\mathrm{HK}-2$ cells.

$\mathrm{Cr}(\mathrm{VI})$ exposure increases apoptosis in $\mathrm{HK}-2$ cells. The results revealed that cells treated with $10 \mu \mathrm{M} \mathrm{K}_{2} \mathrm{Cr}_{2} \mathrm{O}_{7}$ for $48 \mathrm{~h}$ exhibited a viability of $\sim 20-30 \%$. Since a significant reduction in cell viability from 24 to $48 \mathrm{~h}$ suggested that apoptosis-regulating 

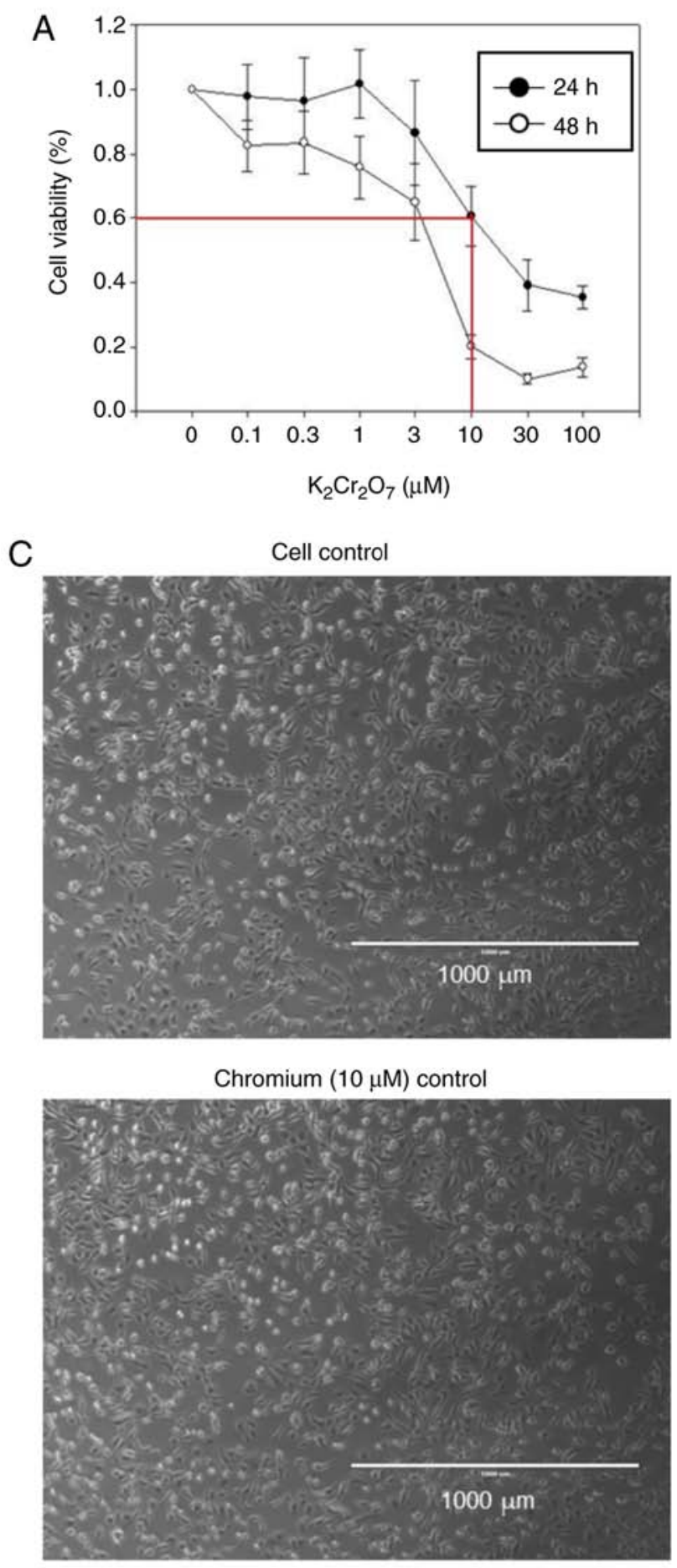
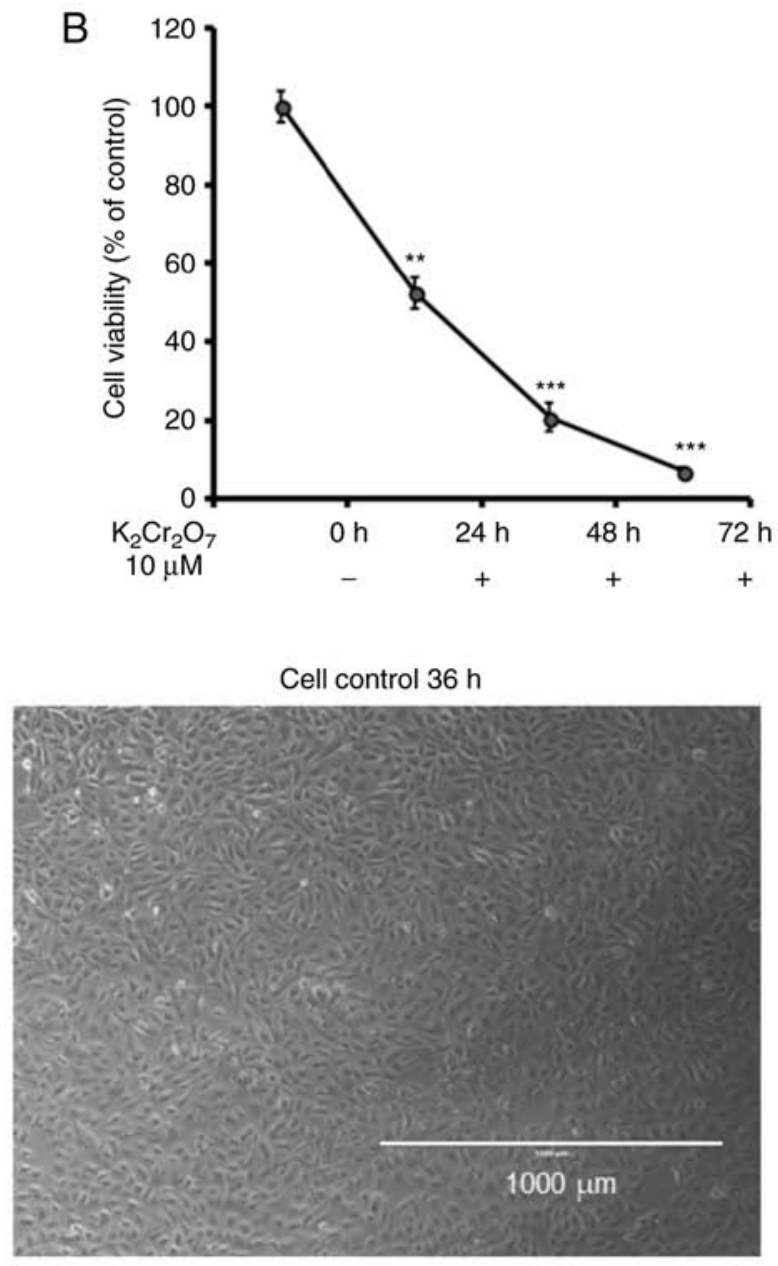

Chromium $(10 \mu \mathrm{M}) 36 \mathrm{~h}$

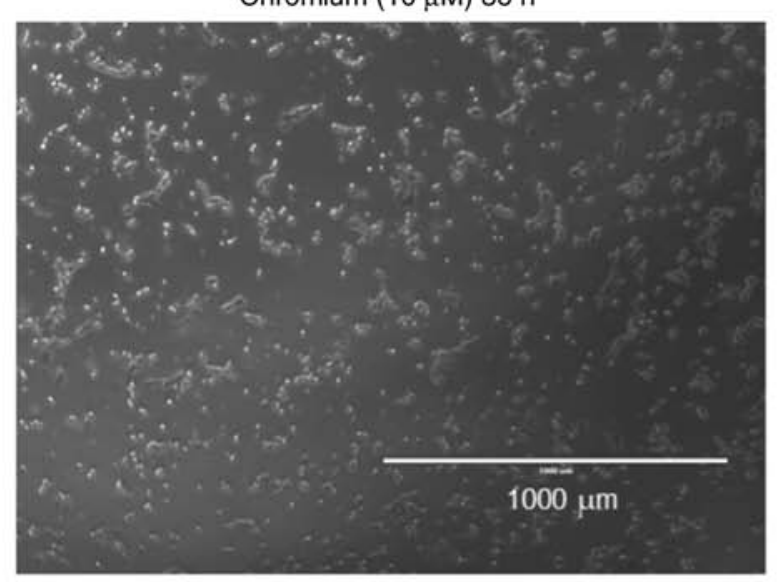

Figure 1. Toxic effect of $\mathrm{K}_{2} \mathrm{Cr}_{2} \mathrm{O}_{7}$ in HK-2 cells. HK-2 cells were treated with various concentrations of $\mathrm{K}_{2} \mathrm{Cr}_{2} \mathrm{O}_{7}$, and control HK-2 cells were treated with $\mathrm{H}_{2} \mathrm{O}$. (A) Cell viability at 24 and $48 \mathrm{~h}$ after exposure to various concentrations of $\mathrm{K}_{2} \mathrm{Cr}_{2} \mathrm{O}_{7}$. (B) Cell viability at $0,24,48$, and $72 \mathrm{~h}$ after exposure to $10 \mu \mathrm{M} \mathrm{K}_{2} \mathrm{Cr}_{2} \mathrm{O}_{7}$. (C) Morphology of $\mathrm{HK}-2$ cells after $36 \mathrm{~h}$ of exposure to $10 \mu \mathrm{M} \mathrm{K}_{2} \mathrm{Cr}_{2} \mathrm{O}_{7}$. The scale bar indicates 1,000 $\mu \mathrm{m}$. Data are presented as the mean $\pm \mathrm{SD}$. ** $\mathrm{P}<0.01$ and *** $\mathrm{P}<0.001$ compared with $0 \mathrm{~h}$, respectively. $\mathrm{K}_{2} \mathrm{Cr}_{2} \mathrm{O}_{7}$, potassium dichromate.

proteins were induced, the protein lysates were collected during a 24 to 48 -h time frame. The protein lysates of HK-2 cells exposed to $\mathrm{K}_{2} \mathrm{Cr}_{2} \mathrm{O}_{7}$ were harvested at $24,36,40$, and $45 \mathrm{~h}$ (Fig. 3A) and the quantitative results are presented in Fig. 3B-E. The activation of caspase- 3 and cleavage of PARP indicated activation of the apoptotic pathway (22). After $24 \mathrm{~h}$ of $\mathrm{K}_{2} \mathrm{Cr}_{2} \mathrm{O}_{7}$ exposure, the expression levels of cleaved PARP and cleaved caspase- 3 were significantly upregulated. In addition, the expression of Bcl-2, which prevents the release of mitochondrial apoptogenic factors such as cytochrome $c$ and $\operatorname{AIF}$ (23), was significantly suppressed in $\mathrm{K}_{2} \mathrm{Cr}_{2} \mathrm{O}_{7}$-exposed $\mathrm{HK}-2$ cells, indicating that $10 \mu \mathrm{M} \mathrm{K}_{2} \mathrm{Cr}_{2} \mathrm{O}_{7}$ exposure induced apoptotic pathways at $24 \mathrm{~h}$ post- $\mathrm{K}_{2} \mathrm{Cr}_{2} \mathrm{O}_{7}$ treatment. At other time-points, similar expression patterns were observed. However, there was no significant difference between the control and 10- $\mu \mathrm{M} \mathrm{K}_{2} \mathrm{Cr}_{2} \mathrm{O}_{7}$-exposed cells at 36, 40 and $45 \mathrm{~h}$ due to high standard deviation. 

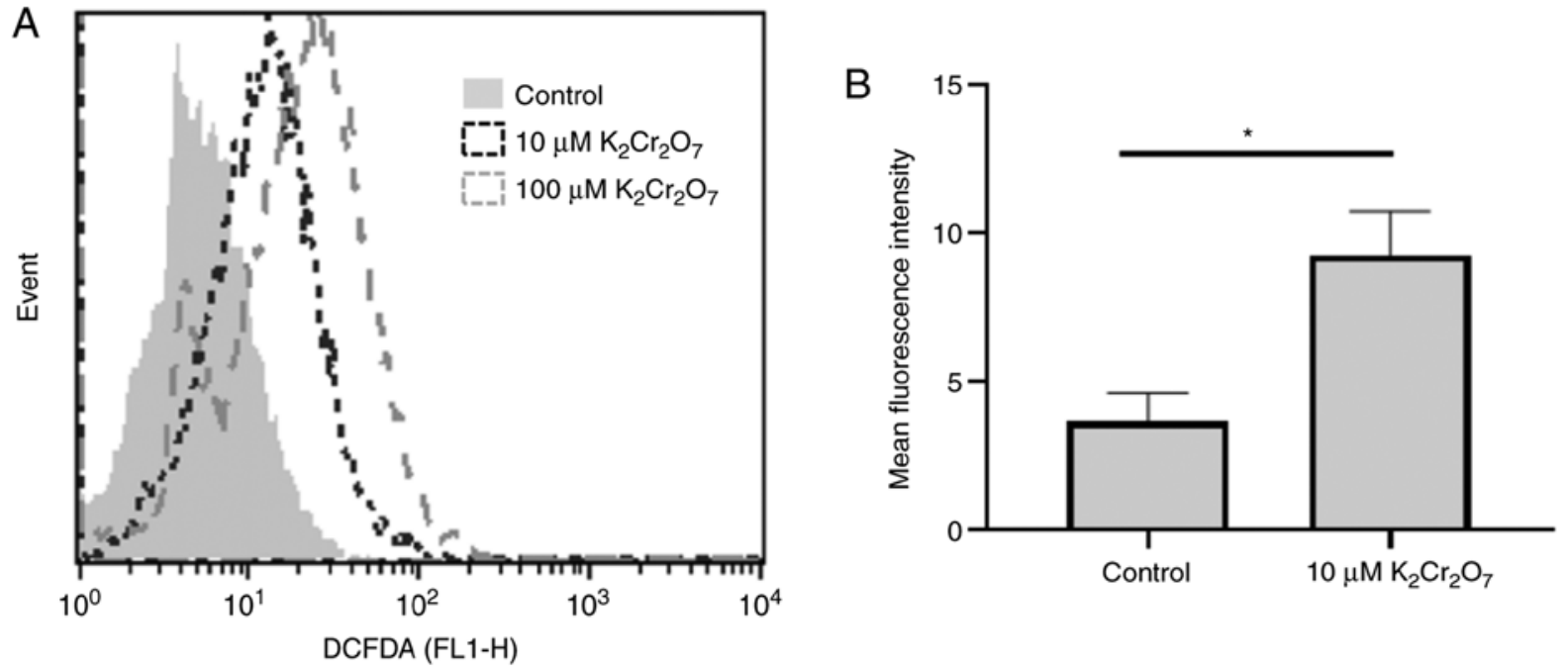

Figure 2. Intracellular ROS detection in $\mathrm{K}_{2} \mathrm{Cr}_{2} \mathrm{O}_{7}$-treated HK-2 cells. (A) Detection of ROS levels by flow cytometry after 10 and $100 \mu \mathrm{M} \mathrm{K}_{2} \mathrm{Cr}_{2} \mathrm{O}_{7}$ treatment for 30 min. (B) Quantification of ROS levels ( $\mathrm{n}=3$ ). Data are presented as the mean $\pm \mathrm{SD}$. ${ }^{*} \mathrm{P}<0.05,10 \mu \mathrm{M} \mathrm{K}_{2} \mathrm{Cr}_{2} \mathrm{O}_{7}$ exposure vs. the control. ROS, reactive oxygen species; $\mathrm{K}_{2} \mathrm{Cr}_{2} \mathrm{O}_{7}$, potassium dichromate.

A

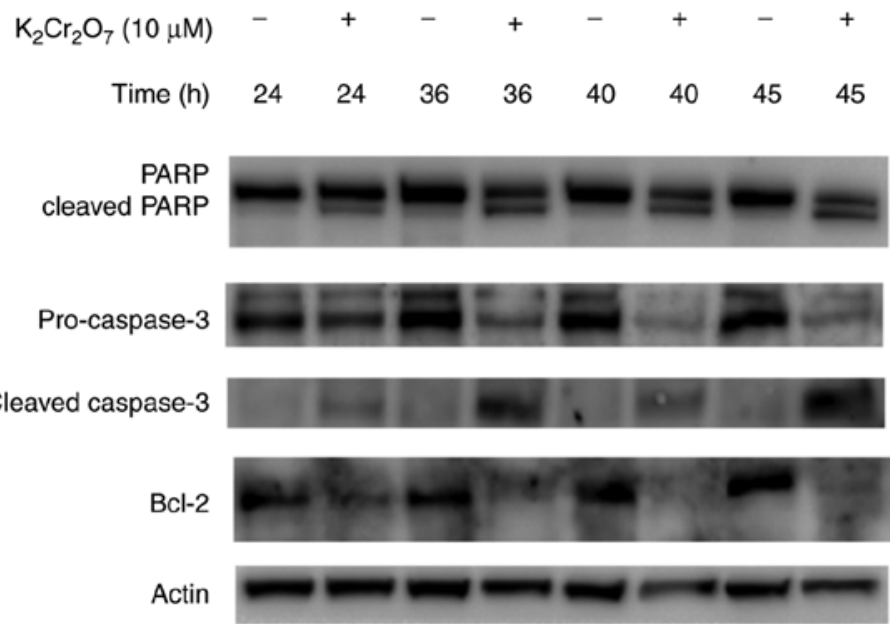

B

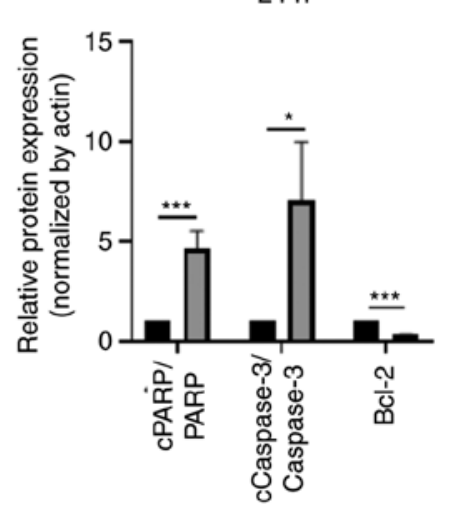

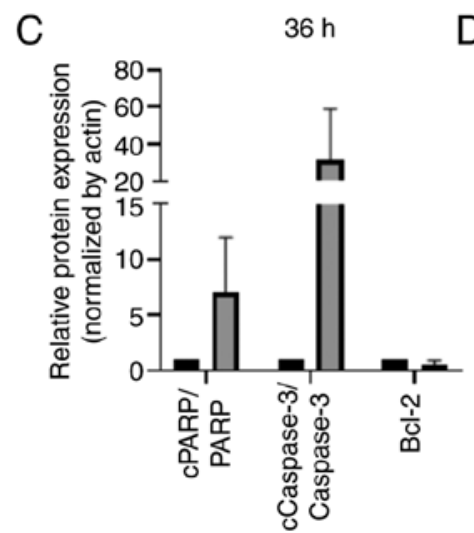

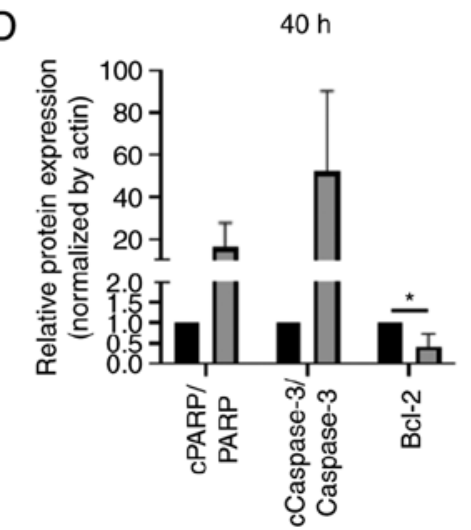

E

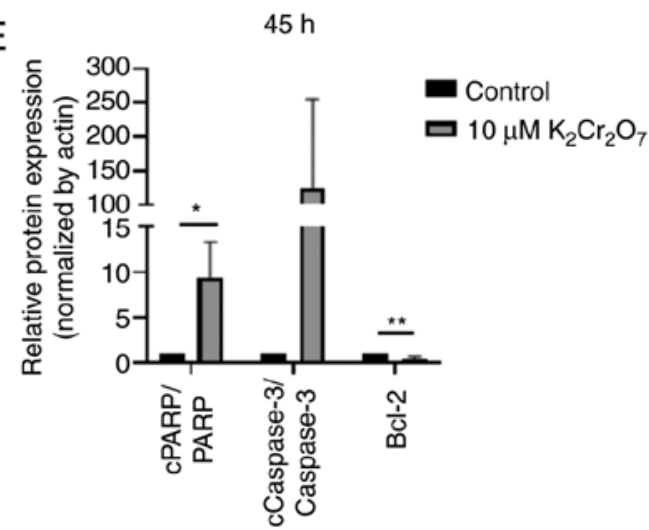

Figure 3. Evaluation of apoptotic markers. HK-2 cells were exposed to $10 \mu \mathrm{M} \mathrm{K}_{2} \mathrm{Cr}_{2} \mathrm{O}_{7}$ and protein lysates were collected at different time-points (24, 36, 40, $45 \mathrm{~h}$ after $\mathrm{K}_{2} \mathrm{Cr}_{2} \mathrm{O}_{7}$ treatment). (A) The expression of PARP, cleaved PARP, pro-caspase-3, cleaved caspase-3, and Bcl-2 in HK-2 cells. The relative protein expression levels at (B) 24 (C) 36 (D) 40 and (E) $45 \mathrm{~h}$ are presented. ${ }^{*} \mathrm{P}<0.05,{ }^{* *} \mathrm{P}<0.01$ and ${ }^{* * * *} \mathrm{P}<0.001 .10 \mu \mathrm{M} \mathrm{K}_{2} \mathrm{Cr}_{2} \mathrm{O}_{7}$ exposure vs. the control at various time-points. $\mathrm{K}_{2} \mathrm{Cr}_{2} \mathrm{O}_{7}$, potassium dichromate; PARP, poly (ADP-ribose) polymerase; AIF, apoptosis-inducing factor.

Cr(VI) exposure increases not only the intrinsic, but also the extrinsic and caspase-independent apoptosis in HK-2 cells. Previous studies have revealed that $\mathrm{Cr}(\mathrm{VI})$ toxicity induced cell apoptosis mainly via intrinsic mitochondrial pathways (5). Our results showed that the expression levels of molecules involved in the intrinsic pathway (BAX, cytochrome $c$ ), 
A

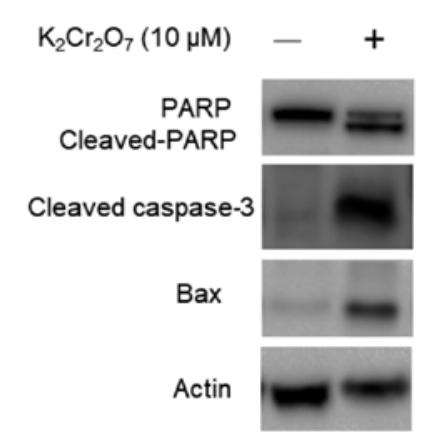

B

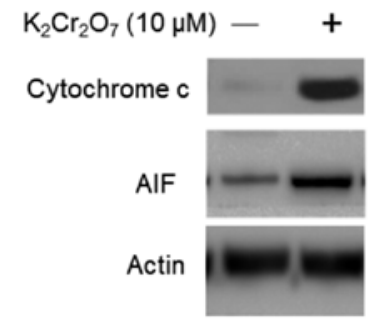

C

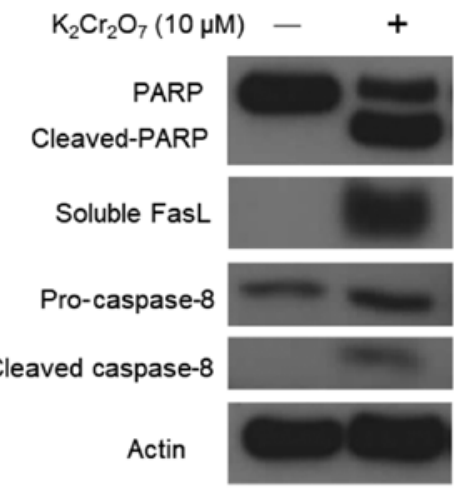

D

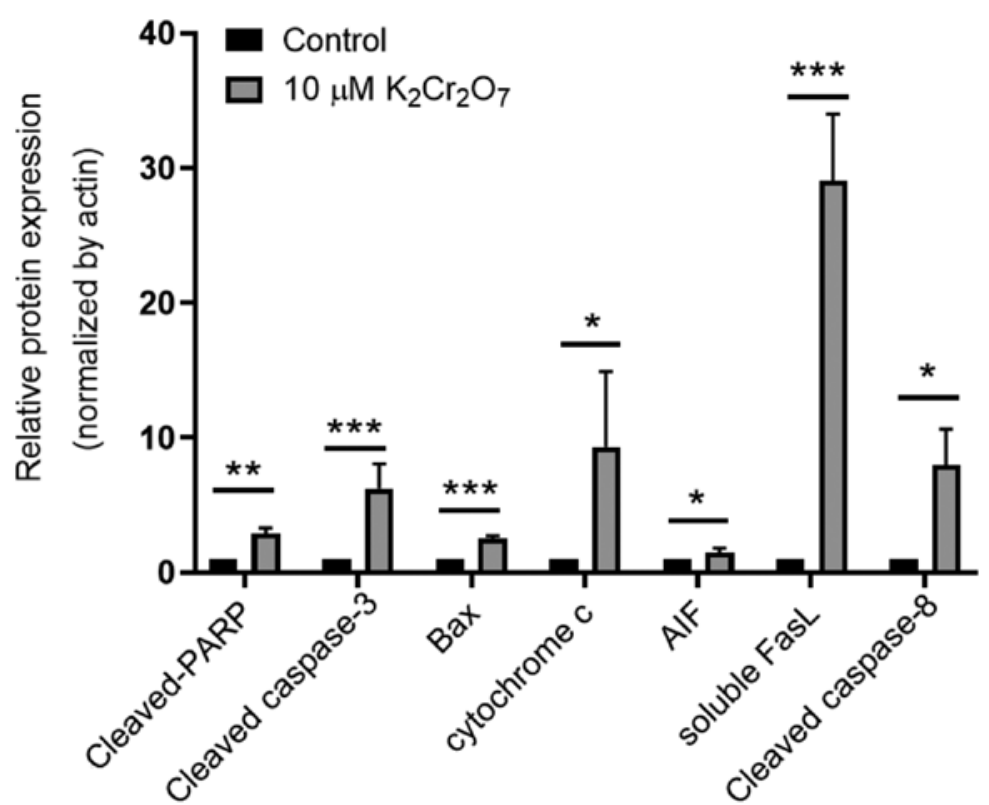

Figure 4. Evaluation of apoptotic pathways. (A) The expression levels of PARP, cleaved PARP, cleaved caspase-3, and Bax are presented. (B) The expression levels of AIF and cytochrome $c$ are presented. (C) The expression levels of soluble FasL, pro-caspase-8, and cleaved caspase-8 were assessed. (D) Quantification of the western blot assay. The data represent the mean $\pm \mathrm{SD}$ of three independent experiments. ${ }^{*} \mathrm{P}<0.05,{ }^{* * *} \mathrm{P}<0.01$ and ${ }^{* * * *} \mathrm{P}<0.001,10 \mu \mathrm{M} \mathrm{K} \mathrm{K}_{2} \mathrm{Cr}_{2} \mathrm{O}_{7}$ exposure vs. the control. PARP, poly (ADP-ribose) polymerase; AIF, apoptosis-inducing factor; FasL, Fas ligand; $\mathrm{K}_{2} \mathrm{Cr}_{2} \mathrm{O}_{7}$, potassium dichromate.

caspase-independent pathway (AIF), and extrinsic pathway (soluble FasL and cleaved caspase-8) were significantly induced after $45 \mathrm{~h}$ of incubation in the presence of $10 \mu \mathrm{M}$ $\mathrm{K}_{2} \mathrm{Cr}_{2} \mathrm{O}_{7}$ (Fig. 4). These findings indicated that these pathways contributed to $\mathrm{Cr}(\mathrm{VI})$-mediated human renal cell death. The summary of this study is outlined in Fig. 5.

\section{Discussion}

Exposure to $\mathrm{Cr}(\mathrm{VI})$ affects various physiological events, and $\mathrm{Cr}(\mathrm{VI})$-induced apoptosis has been reported by previous studies. In human diploid and normal fibroblasts and in HeLa human cervical cancer cells, reduced form of $\mathrm{Cr}(\mathrm{VI})$ caused DNA strand breaks (24-26). In U937 cells, exposure to $20 \mu \mathrm{M} \mathrm{Cr}$ (VI) for $24 \mathrm{~h}$ induced intrinsic but not extrinsic apoptosis (27). Exposure to $30 \mu \mathrm{M} \mathrm{Cr}(\mathrm{VI})$ induced both $\mathrm{p} 53$-dependent and independent intrinsic mitochondrial apoptosis in HCT116 human colon carcinoma cells (28). Activation of ribosomal protein L3 (rpL3) plays a role in chemotherapeutic drug-induced p53-independent apoptosis in colon and lung cancer cells $(29,30)$. However, the role of rpL3 in $\mathrm{Cr}(\mathrm{VI})$-induced apoptotic processes is unclear. Another study revealed that Bcl-2 and p21 were downregulated after HCT-116 cells were exposed to $30 \mu \mathrm{M} \mathrm{Cr}$ (VI) (5). In a rat model, a single subcutaneous injection of $\mathrm{K}_{2} \mathrm{Cr}_{2} \mathrm{O}_{7}$ at $15 \mathrm{mg} / \mathrm{kg}$ induced the intrinsic mitochondrial pathway in kidneys (19). Clinically, $\mathrm{Cr}(\mathrm{VI})$ exposure often causes acute renal failure that may result in permanent hemodialysis or even death, and renal injury has mainly been detected in renal proximal tubular epithelial cells (31). Therefore, investigating the mechanism of $\mathrm{Cr}(\mathrm{VI})$-induced apoptosis in renal cells is an important issue. To develop an optimal strategy to treat acute $\mathrm{Cr}(\mathrm{VI})$ intoxication, the apoptosis mechanism in human kidney cells under a curable dose was evaluated. According to a clinical study, chromium at a concentration of $10 \mathrm{mg} / \mathrm{l}$ (approximate $34 \mu \mathrm{M}$ ) or greater in human blood is considered to be lethal for human life (32). A case study indicated that a patient with chromium blood concentration of $3.4 \mathrm{mg} / \mathrm{l}$ fortunately survived after intermittent hemodialysis treatment (33). Compared to cells exposed to $10 \mu \mathrm{M}$ of $\mathrm{Cr}(\mathrm{VI})$, low cell viability was observed when cells were exposed to 30 and $100 \mu \mathrm{M}$ for 24 and $48 \mathrm{~h}$ (Fig. 1A). 


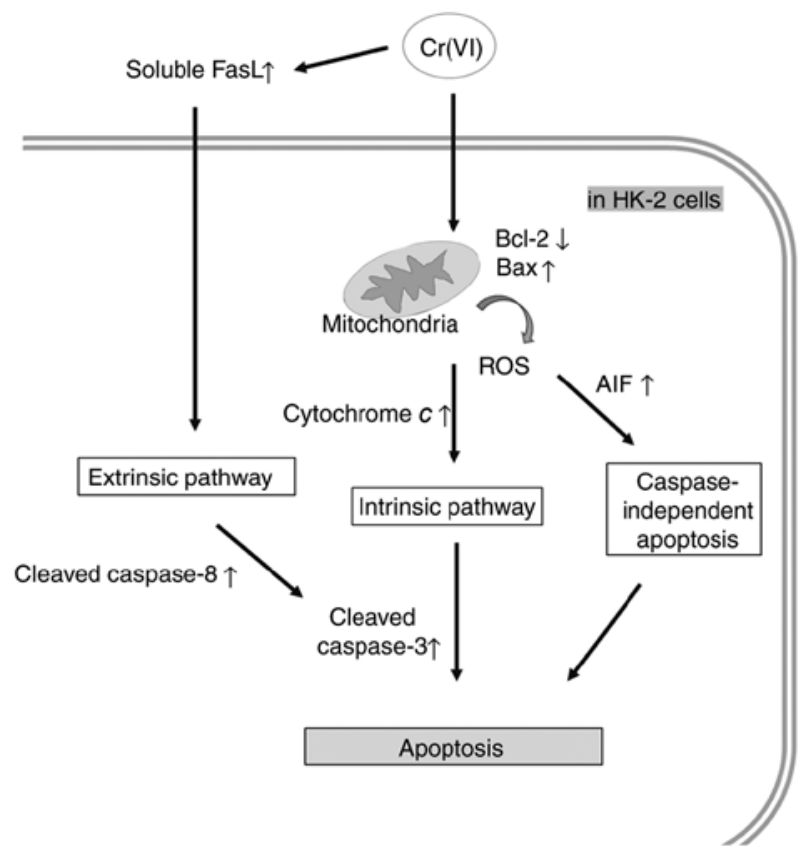

Figure 5. Schematic of the proposed hypothesis. $\mathrm{Cr}(\mathrm{VI})$ toxicity induced ROS and subsequently triggered intrinsic and extrinsic apoptotic pathways in human epithelial renal proximal tubule cells. Dashed lines indicate the unknown regulatory mechanism of sFasL post-Cr(VI) exposure. $\mathrm{Cr}(\mathrm{VI})$, hexavalent chromium; ROS, reactive oxygen species; sFasL, soluble FasL.

Conversely, cell viability was relatively high when cells were exposed to low concentrations of $\mathrm{Cr}(\mathrm{VI})(<10 \mu \mathrm{M})$. Therefore, the present results also indicated that higher concentrations were lethal and lower doses may not induce apoptosis. $\mathrm{Cr}(\mathrm{VI})$ toxicity at $10 \mu \mathrm{M}(2.95 \mathrm{mg} / \mathrm{l})$ was selected to induce apoptosis in the HK-2 human proximal tubular epithelial cell line.

The intrinsic pathway is regulated by pro-apoptotic and anti-apoptotic proteins such as Bax and Bcl-xL, respectively (22). These proteins alter the fate of cytochrome $c$ release and activation of the caspase cascade, which regulate the permeability of the outer mitochondrial membrane (22). Increased Bax and decreased Bcl-2 protein expression indicated that the intrinsic mitochondrial apoptotic pathway was induced in HK-2 cells (Figs. 3 and 4). AIF is a pro-apoptotic protein released from the mitochondria, and its nuclear translocation caused DNA fragmentation and was involved in caspase-independent apoptosis $(34,35)$. Extrinsic apoptotic pathways initiate apoptosis via the interaction between ligands and transmembrane receptors that belong to the tumor necrosis factor (TNF) receptor gene superfamily (22). Induction of extrinsic apoptosis was observed in mouse glomerular podocytes when they were exposed to toxic metals such as arsenite, cadmium, and mercury (36). Increased expression of soluble FasL and cleaved caspase-8 was detected after $10 \mu \mathrm{M}$ $\mathrm{Cr}(\mathrm{VI})$ toxicity. Soluble FasL is well known as a degradation product of the membrane form of FasL by matrix metalloproteinases $(37,38)$. Previous studies have documented that chromium had the potential to enhance the function of matrix metalloproteinases $(39,40)$, which may explain the increased ratio between soluble and membrane FasL in the present results. In addition, the prevalence of the soluble form in association with the increased activation of caspase- 8 (cleaved caspase-8) indicated the possible active role of soluble FasL in chromium-induced HK-2 cell apoptosis. Therefore, the present results indicated that $\mathrm{Cr}(\mathrm{VI})$ toxicity for $48 \mathrm{~h}$ triggered the extrinsic apoptotic pathway. To the best of our knowledge, this study is the first to observe the induction of extrinsic apoptotic markers in $\mathrm{Cr}(\mathrm{VI})$-exposed human renal cells. However, the mechanism of $\mathrm{Cr}(\mathrm{VI})$-induced soluble FasL release is still unknown. The crosstalk between tumor necrosis factors and ROS may be a potential explanation (41), but further studies are required to confirm this hypothesis.

The limitation of the present study is that the conclusions were supported by one technique in one cell line. For confirmation, more experiments are required in future studies. For example, cell death can be also detected via BrdU staining assay and Annexin V staining assay at each time-point. Inhibition of intrinsic and extrinsic apoptosis-dependent pathways via specific inhibitors on caspase- 8 and caspase- 9 may further confirm the most critical pathways at specific time-points. To further investigate the role of $\mathrm{Cr}(\mathrm{VI})$-induced ROS production, treatments with antioxidants or ROS scavengers are strategies for future experiments. In addition, performing animal experiments may strengthen our conclusion.

Collectively, not only intrinsic but also extrinsic apoptotic pathway-related apoptotic markers were activated in an immortalized proximal tubular epithelial cell line after exposure to $10 \mu \mathrm{M}$ activated $\mathrm{Cr}(\mathrm{VI})$. The experimental dosage of $\mathrm{Cr}(\mathrm{VI})$ was similar to the $\mathrm{Cr}(\mathrm{VI})$ dosage that causes acute renal dysfunction. It is anticipated that the present study may be beneficial in designing optimal treatments for acute $\mathrm{Cr}(\mathrm{VI})$ toxicity in the future.

\section{Acknowledgements}

The authors would like to thank Professor Jung-San Chang (Department of Renal Care, College of Medicine, Kaohsiung Medical University) for scientific discussions and technical assistance.

\section{Funding}

The present study was supported by grants from the Kaohsiung Medical University Hospital (grant no. KMUH103-3M52).

\section{Availability of data and materials}

The datasets used and/or analyzed during the present study are available from the corresponding author upon reasonable request.

\section{Authors' contributions}

YHW, JCL and IJY designed the study. PLW and FWC performed the experiments. YHW, TYW, TJL, MCY, YLS, YHL, and IJY analyzed the data and interpreted the results. All authors read and approved the final version of the manuscript and agree to be accountable for all aspects of the research in ensuring that the accuracy or integrity of any part of the work are appropriately investigated and resolved. 


\section{Ethics approval and consent to participate}

Not applicable.

\section{Patient consent for publication}

Not applicable.

\section{Competing interests}

The authors declare that they have no competing interests.

\section{References}

1. Wang XF, Xing ML, Shen Y, Zhu X and Xu LH: Oral administration of $\mathrm{Cr}(\mathrm{VI})$ induced oxidative stress, DNA damage and apoptotic cell death in mice. Toxicology 228: 16-23, 2006.

2. Sun H, Brocato J and Costa M: Oral chromium exposure and toxicity. Curr Environ Health Rep 2: 295-303, 2015

3. Izbicki JA, Wright MT, Seymour WA, BlaineMcCleskey R, Fram MS, Belitz KF and Esser BK: Cr(VI) occurrence and geochemistry in water from public-supply wells in California. Appl Geochem 63: 203-217, 2015.

4. Chen Y, An D, Sun S, Gao J and Qian L: Reduction and removal of chromium VI in water by powdered activated carbon. Materials (Basel) 11: pii: E269, 2018.

5. Chiu A, Shi XL, Lee WK, Hill R, Wakeman TP, Katz A, Xu B, Dalal NS, Robertson JD, Chen C, et al: Review of chromium (VI) apoptosis, cell-cycle-arrest, and carcinogenesis. J Environ Sci Health C Environ Carcinog Ecotoxicol Rev 28: 188-230, 2010.

6. Hu G, Zheng P, Feng H and Jia G: Imbalance of oxidative and reductive species involved in chromium(VI)-induced toxic effects. Reactive Oxygen Species 3: 1, 2017.

7. Liu KJ and Shi X: In vivo reduction of chromium (VI) and its related free radical generation. Mol Cell Biochem 222: 41-47, 2001.

8. Pan TL, Wang PW, Chen CC, Fang JY and Sintupisut N: Functional proteomics reveals hepatotoxicity and the molecular mechanisms of different forms of chromium delivered by skin administration. Proteomics 12: 477-489, 2012.

9. Bright P, Burge PS, O'Hickey SP, Gannon PF, Robertson AS and Boran A: Occupational asthma due to chrome and nickel electroplating. Thorax 52: 28-32, 1997.

10. Costa M: Toxicity and carcinogenicity of $\mathrm{Cr}(\mathrm{VI})$ in animal models and humans. Crit Rev Toxicol 27: 431-442, 1997.

11. Verschoor MA, Bragt PC, Herber RF, Zielhuis RL and Zwennis WC: Renal function of chrome-plating workers and welders. Int Arch Occup Environ Health 60: 67-70, 1988.

12. Wedeen RP and Qian LF: Chromium-induced kidney disease. Environ Health Perspect 92: 71-74, 1991.

13. Sharma BK, Singhal PC and Chugh KS: Intravascular haemolysis and acute renal failure following potassium dichromate poisoning. Postgrad Med J 54: 414-415, 1978.

14. Ellis EN, Brouhard BH, Lynch RE, Dawson EB, Tisdell R, Nichols MM and Ramirez F: Effects of hemodialysis and dimercaprol in acute dichromate poisoning. J Toxicol Clin Toxicol 19: 249-258, 1982

15. Leonard SS, Roberts JR, Antonini JM, Castranova V and Shi X: $\mathrm{PbCrO} 4$ mediates cellular responses via reactive oxygen species. Mol Cell Biochem 255: 171-179, 2004.

16. Sinha K, Das J, Pal PB and Sil PC: Oxidative stress: The mitochondria-dependent and mitochondria-independent pathways of apoptosis. Arch Toxicol 87: 1157-1180, 2013.

17. Quinteros FA, Poliandri AH, Machiavelli LI, Cabilla JP and Duvilanski BH: In vivo and in vitro effects of chromium VI on anterior pituitary hormone release and cell viability. Toxicol Appl Pharmacol 218: 79-87, 2007.

18. Xiao F, Li Y, Dai L, Deng Y, Zou Y, Li P, Yang Y and Zhong C: Hexavalent chromium targets mitochondrial respiratory chain complex I to induce reactive oxygen species-dependent caspase-3 activation in L-02 hepatocytes. Int J Mol Med 30: 629-635, 2012.

19. Molina-Jijon E, Tapia E, Zazueta C, El Hafidi M, Zatarain-Barrón ZL, Hernández-Pando R, Medina-Campos ON, Zarco-Márquez G, Torres I and Pedraza-Chaverri J: Curcumin prevents $\mathrm{Cr}(\mathrm{VI})$-induced renal oxidant damage by a mitochondrial pathway. Free Radic Biol Med 51: 1543-1557, 2011.
20. Redza-Dutordoir M and Averill-Bates DA: Activation of apoptosis signalling pathways by reactive oxygen species. Biochim Biophys Acta 1863: 2977-2992, 2016.

21. Lin TJ, Huang YL, Chang JS, Liu KT, Yen MC, Chen FW, Shih YL, Jao JC, Huang PC and Yeh IJ: Optimal dosage and early intervention of L-ascorbic acid inhibiting $\mathrm{K}_{2} \mathrm{Cr}_{2} \mathrm{O}_{7}$-induced renal tubular cell damage. J Trace Elem Med Biol 48: 1-7, 2018.

22. Elmore S: Apoptosis: A review of programmed cell death. Toxicol Pathol 35: 495-516, 2007.

23. Tsujimoto Y: Role of Bcl-2 family proteins in apoptosis: apoptosomes or mitochondria? Genes Cells 3: 697-707, 1998.

24. Snyder RD: Role of active oxygen species in metal-induced DNA strand breakage in human diploid fibroblasts. Mutat Res 193: 237-246, 1988

25. Wakeman TP, Kim WJ, Callens S, Chiu A, Brown KD and $\mathrm{Xu}$ B: The ATM-SMC1 pathway is essential for activation of the chromium[VI]-induced S-phase checkpoint. Mutat Res 554: 241-251, 2004.

26. Ha L, Ceryak S and Patierno SR: Generation of S phase-dependent DNA double-strand breaks by $\mathrm{Cr}(\mathrm{VI})$ exposure: Involvement of ATM in $\mathrm{Cr}(\mathrm{VI})$ induction of gamma-H2AX. Carcinogenesis 25: 2265-2274, 2004.

27. Hayashi Y, Kondo T, Zhao QL, Ogawa R, Cui ZG, Feril LB Jr, Teranishi $H$ and Kasuya M: Signal transduction of p53-independent apoptotic pathway induced by hexavalent chromium in U937 cells. Toxicol Appl Pharmacol 197: 96-106, 2004.

28. Hill R, Leidal AM, Madureira PA, Gillis LD, Cochrane HK, Waisman DM, Chiu A and Lee PW: Hypersensitivity to chromium-induced DNA damage correlates with constitutive deregulation of upstream p53 kinases in p21-/-HCT116 colon cancer cells. DNA Repair (Amst) 7: 239-252, 2008.

29. Pagliara V, Saide A, Mitidieri E, d'Emmanuele di Villa Bianca R, Sorrentino R, Russo G and Russo A: 5-FU targets rpL3 to induce mitochondrial apoptosis via cystathionine-beta-synthase in colon cancer cells lacking p53. Oncotarget 7: 50333-50348, 2016.

30. Russo A, Saide A, Cagliani R, Cantile M, Botti G and Russo G: rpL3 promotes the apoptosis of p53 mutated lung cancer cells by down-regulating $\mathrm{CBS}$ and $\mathrm{NF \kappa B}$ upon 5-FU treatment. Sci Rep 6: 38369, 2016.

31. Parveen K, Khan MR and Siddiqui WA: Pycnogenol prevents potassium dichromate $\mathrm{K} 2 \mathrm{Cr} 2 \mathrm{O} 7$-induced oxidative damage and nephrotoxicity in rats. Chem Biol Interact 181: 343-350, 2009.

32. Pedersen RS and Morch PT: Chromic acid poisoning treated with acute hemodialysis. Nephron 22: 592-595, 1978.

33. KhanSaif R, Aparna Q, Shahzad S and Haque F: Chromium induced AKI: Case with protean implications. Annals Tropical Medicine Public Health 7: 136-138, 2014.

34. Tait SW and Green DR: Caspase-independent cell death: Leaving the set without the final cut. Oncogene 27: 6452-6461, 2008.

35. Ranjan A and Iwakuma T: Non-canonical cell death induced by p53. Int J Mol Sci 17: pii: E2068, 2016.

36. Eichler T, Ma Q, Kelly C, Mishra J, Parikh S, Ransom RF, Devarajan P and Smoyer WE: Single and combination toxic metal exposures induce apoptosis in cultured murine podocytes exclusively via the extrinsic caspase 8 pathway. Toxicol Sci 90: 392-399, 2006

37. Vargo-Gogola T, Crawford HC, Fingleton B and Matrisian LM: Identification of novel matrix metalloproteinase-7 (matrilysin) cleavage sites in murine and human Fas ligand. Arch Biochem Biophys 408: 155-161, 2002.

38. Musial K and Zwolinska D: Matrix metalloproteinases and soluble Fas/FasL system as novel regulators of apoptosis in children and young adults on chronic dialysis. Apoptosis 16: 653-659, 2011.

39. Cammarota M, Lamberti M, Masella L, Galletti P, De Rosa M, Sannolo N and Giuliano M: Matrix metalloproteinases and their inhibitors as biomarkers for metal toxicity in vitro. Toxicol In Vitro 20: 1125-1132, 2006.

40. Wan R, Mo Y, Zhang X, Chien S, Tollerud DJ and Zhang Q: Matrix metalloproteinase- 2 and -9 are induced differently by metal nanoparticles in human monocytes: The role of oxidative stress and protein tyrosine kinase activation. Toxicol Appl Pharmacol 233: 276-285, 2008

41. Blaser H, Dostert C, Mak TW and Brenner D: TNF and ROS crosstalk in inflammation. Trends Cell Biol 26: 249-261, 2016.

This work is licensed under a Creative Commons Attribution-NonCommercial-NoDerivatives 4.0 International (CC BY-NC-ND 4.0) License. 